\title{
UVA-UVB activation of hydrogen peroxide and persulfate for Advanced Oxidation Processes: Efficiency, mechanism and effect of various water constituents
}

\author{
Wenyu Huang ${ }^{\mathrm{a}, \mathrm{b}^{*}}$, Angelica Bianco ${ }^{\mathrm{a}}$, Marcello Brigante ${ }^{\mathrm{a}^{*}}$, Gilles Mailhot $^{\mathrm{a}}$ \\ ${ }^{a}$ Université Clermont Auvergne, CNRS, SIGMA Clermont, Institut de Chimie de Clermont-Ferrand, \\ F-63000 Clermont-Ferrand, France. \\ ${ }^{\mathrm{b}}$ School of the Environment, Guangxi University, Nanning 530004, China
}

*Corresponding authors : huangwenyu@gxu.edu.cn (WH) and marcello.brigante@uca.fr (MB)

\begin{abstract}
In the present work we investigate the activation efficiency of $\mathrm{H}_{2} \mathrm{O}_{2}$ and $\mathrm{S}_{2} \mathrm{O}_{8}{ }^{2-}$ using UVA and UVB radiation. Bisphenol-A (BPA) is used as model pollutants to estimate the oxidative process efficiency in simulated and real sewage treatment plant waters. Particular attention is paid to the BPA removal efficiency and to the radical mechanism involvement considering the effect of typical
\end{abstract}


inorganic water constituents (carbonates and chloride ions) and organic matter. Despite a detrimental effect observed when carbonate ions are in solution using both hydrogen peroxide and persulafate, the presence of high chloride ions concentration was found to improve BPA removal using $\mathrm{S}_{2} \mathrm{O}_{8}{ }^{2-}$ as radical precursor. This enhancement, investigated combining chemical kinetic model approach and laser flash photolysis experiments, is attributed to the formation of hydroxyl radical and chlorine radical species from sulfate radical. Different transformation products are identified by means of GC-MS and HPLC-MS analyses. Moreover, experiments using sewage treatment plant water (STPW) spiked with BPA are performed in order to assess the efficiency of oxidative processes in a simulated treatment systems activated using UVA+UVB radiations.

Keywords: AOPs, pollutant degradation, chloride ions effect, hydroxyl and sulfate radical, Bisphenol A

\section{Introduction}

Treatment efficiency of recalcitrant organic pollutants in aqueous effluents using oxidant species precursors such as hydrogen peroxide $\left(\mathrm{H}_{2} \mathrm{O}_{2}\right)$ and persulfate $\left(\mathrm{S}_{2} \mathrm{O}_{8}{ }^{2-}\right)$ has been investigated under UVC radiation [1-5]. UVC lamps are mercury made, fragile and they require considerable more energy than UVA, UVB lamps [6] which can also be substituted by LED to reduce the operating cost. UVC-LED efficiency is less than $3 \%$ making their utilization not suitable for long time wastewater treatments. For these reasons, application of UVA and UVB radiation to improve water 
depollution processes can offer many advantages. Following this idea, iron-complexes are recently used to initiate or improve pollutant removal using $\mathrm{H}_{2} \mathrm{O}_{2}$ and $\mathrm{S}_{2} \mathrm{O}_{8}{ }^{2}$ activation in the presence of solar spectrum UV radiation (UVA and UVB) [7-11]. In this photo-activated processes, generated hydroxyl and sulfate radicals $\left(\left(\mathrm{HO}^{\bullet}\right.\right.$ and $\left.\mathrm{SO}_{4}{ }^{\bullet-}\right)$ can react with a wide range of organic pollutants due to their high redox potential. And the redox potentials vs NHE and in standard conditions of $\mathrm{HO}^{\bullet}$ and $\mathrm{SO}_{4}{ }^{--}$is $2.7 \mathrm{~V}$ and $2.6 \mathrm{~V}$ respectively [12]. Therefore, application $\mathrm{H}_{2} \mathrm{O}_{2}$ or $\mathrm{S}_{2} \mathrm{O}_{8}{ }^{2-}$ photoactivation in wastewater treatment is now taken into account for emerging contaminant abatement. Comparing to $\mathrm{HO}^{\bullet}$ based processes, $\mathrm{SO}_{4}{ }^{\bullet-}$ based methods from activation Persulfate (PS, $\mathrm{S}_{2} \mathrm{O}_{8}{ }^{2-}$ ) have a series of advantages, and attract many researches [13]. However, the presence of organic and inorganic species (such as carbonate and chloride ions) in natural and wastewater may strongly influence the efficiency of oxidation treatment $[14,15]$. For this reason, several investigations providing a better understanding of natural occurring ions effect on the oxidative process are reported [16-18]. Generally, chloride ions $\left(\mathrm{Cl}^{-}\right)$can significantly inhibit efficiency of UVC based activation of $\mathrm{H}_{2} \mathrm{O}_{2}$ and $\mathrm{S}_{2} \mathrm{O}_{8}{ }^{2-}$ due to their radical scavenging effect [19, 20]. However, in the presence of chloride ions, generated reactive species such as chlorine radical $\left(\mathrm{Cl}^{\bullet}\right)$ and dichlorine radical anion $\left(\mathrm{Cl}_{2}{ }^{\bullet-}\right)$ could also react with organic pollutants being more selective [16]. On the other hand, it was suggested that the chain reaction triggered by $\mathrm{Cl}^{-}$and $\mathrm{SO}_{4}{ }^{--}$can result in the production of $\mathrm{HO}^{\bullet}[21,22]$ and conflicting results are reported in different studies on this topic. For example, different researchers $[17,22,23]$ reported that the presence of $\mathrm{Cl}^{-}$would inhibit the oxidation of organics, while in other investigations, a negligible effect of chloride ions on the 
$\mathrm{UVC}-\mathrm{H}_{2} \mathrm{O}_{2}$ treatment performances was observed [24]. Moreover, using $\mathrm{SO}_{4}{ }^{\bullet-}$ based oxidation, pollutant's degradation mechanism was found to be modified due to the presence of chloride ions $[25,26]$.

Inorganic carbon $\left(\mathrm{HCO}_{3}{ }^{-} / \mathrm{CO}_{3}{ }^{2-}, \mathrm{pKa}=10.33\right)$ is also an important water constituent that considerably influence the oxidation process. In fact, reactivity of $\mathrm{HCO}_{3}{ }^{-} / \mathrm{CO}_{3}{ }^{2-}$ with $\mathrm{HO}^{\bullet}$ or $\mathrm{SO}_{4}{ }^{\bullet-}$ generates carbonate radical anion $\left(\mathrm{CO}_{3}{ }^{--}\right)[27,28]$ which is generally less reactive toward organic molecules (the second order rate constant with organic compounds in the range $\sim 10^{5}-10^{9} \mathrm{M}^{-1} \mathrm{~s}^{-1}$ ) than $\mathrm{HO}^{\bullet}$ or $\mathrm{SO}_{4}{ }^{\bullet-}$. However, $\mathrm{CO}_{3}{ }^{\bullet-}$ can efficiently react with electron-rich atoms, such as $\mathrm{N}$ and S-containing compounds, phenols and inorganic compounds [15, 29].

Besides, even if the effect of single water constituent could mutually offset or superimpose, the contribution on the oxidation process of different water matrix as a whole was also investigated in several previous researches [30-34]. Kattel et coworkers found strong effect of the natural water composition on the oxidative degradation of emerging micropollutant acesulfame using UVA-induced $\mathrm{H}_{2} \mathrm{O}_{2} / \mathrm{Fe}^{2+}$ and $\mathrm{S}_{2} \mathrm{O}_{8}{ }^{2-} / \mathrm{Fe}^{2+}$ processes [35]. Due to the complexity of different water matrix, the efficiency of $\mathrm{HO}^{\bullet}$ or $\mathrm{SO}_{4}{ }^{\bullet-}$ based oxidation processes (also called AOPs: advanced oxidation processes) strongly depends on the investigated medium and on the target pollutant. In the present work, UVA + UVB (UVA/B) radiation is used to activate $\mathrm{H}_{2} \mathrm{O}_{2}$ and $\mathrm{S}_{2} \mathrm{O}_{8}{ }^{2}$ using Bisphenol A (BPA) as target compound. BPA degradation efficiency is investigated in the presence of natural and wastewaters occurring inorganic constituents such as chloride and hydrogenocarbonate/carbonate ions and in real sewage treatment plant water (STPW). Bimolecular rate constants of reaction of 
BPA and STPW constituents with radicals such as $\mathrm{HO}^{\bullet}, \mathrm{SO}_{4}{ }^{\bullet-}, \mathrm{Cl}_{2}{ }^{\bullet-}$ and $\mathrm{CO}_{3}{ }^{\bullet-}$ are estimated through laser flash photolysis experiments and used in a chemical kinetic model. Finally, radical species involvement in the presence of different water constituents and impact on the oxidative process are discussed.

\section{Materials and methods}

\subsection{Chemicals}

Hydrogen peroxide $\left(\mathrm{H}_{2} \mathrm{O}_{2}\right)$ (30\% in water) is purchased from Fluka, France. Bisphenol A (BPA), sodium persulfate $\left(\mathrm{Na}_{2} \mathrm{~S}_{2} \mathrm{O}_{8}\right)$, sodium chorine $(\mathrm{NaCl})$ and sodium hydrogen carbonate $\left(\mathrm{NaHCO}_{3}\right)$ are obtained from Sigma, France. Perchloric acid $\left(\mathrm{HClO}_{4}\right)$ and sodium hydroxide $(\mathrm{NaOH})$ are used to adjust the $\mathrm{pH}$ of the solutions. $1 \mathrm{mM}$ buffer solution with sodium dihydrogen phosphate $\left(\mathrm{NaH}_{2} \mathrm{PO}_{4}\right)$ and sodium hydrogen phosphate $\left(\mathrm{Na}_{2} \mathrm{HPO}_{4}\right)$ is used to keep $\mathrm{pH}$ value constant at 8.0 during the irradiation time without otherwise stated. All chemicals are used without further purification.

\subsection{Irradiation experiments and analysis}

Irradiations are performed in a cylindrical Pyrex reactor $(500 \mathrm{~mL})$ placed in a rectangular box, equipped, on the top, with four fluorescence lamps whose emitting wavelength is larger than 275 nm (UVA/B radiation). The polychromatic emission spectrum of the irradiation system reaching the solution is recorded using an optical fiber with a charge coupled device (CCD) spectrophotometer 
(Ocean Optics USD $2000+$ UV-vis) which is calibrated using a DH-2000-CAL Deuterium Tungsten Halogen reference lamp. The total irradiance between 275 and $400 \mathrm{~nm}$ reaching the solution is then estimated to be $976 \mu \mathrm{W} \mathrm{cm}{ }^{-2}$. In Figure SM1 emission spectrum of lamps and overlap with absorption spectra of $\mathrm{H}_{2} \mathrm{O}_{2}$ and $\mathrm{S}_{2} \mathrm{O}_{8}{ }^{2-}$ are presented. All experiments are performed at room temperature $(293 \pm 2 \mathrm{~K})$ using a circulation cooling system.

BPA solution ( $43.8 \mu \mathrm{M}$ corresponding to $\left.10 \mathrm{mg} \mathrm{L}^{-1}\right)$ is magnetically stirred with a magnetic bar during the reaction to ensure the homogeneity of solution. All irradiation experiments are performed using a phosphate buffer (total buffer concentration of $0.1 \mathrm{mM}$ ) without otherwise stated. At fixed interval times, $1 \mathrm{~mL}$ of sample is withdrawn and analyzed by ultra performance liquid chromatography (UPLC, ACQUITY, Waters, USA) equipped with photodiode array detector (PDA). The flow rate is $0.25 \mathrm{~mL} \mathrm{~min}^{-1}$ and the mobile phase is a mixture of water and methanol (40/60, v/v). The column is a Zorbax $\mathrm{C} 18$ of $150 \times 4.6 \mathrm{~mm}$ with particle size $5 \mu \mathrm{m}$. BPA disappearance is followed at $225 \mathrm{~nm}$.

HPLC-MS an GC-MS conditions used for degradation identification are reported in the supplementary material section.

The pseudo-first-order decay of BPA is determined by plotting BPA disappearance vs time and using following relation:

$$
\frac{[B P A]_{t}}{[B P A]_{0}}=\exp \left(-k_{a p p} t\right)
$$

Where $[\mathrm{BPA}]_{0}$ and $[\mathrm{BPA}]_{\mathrm{t}}$ are the initial and remaining concentrations of BPA at time $t, k_{\text {app }}$ is the 
pseudo-first-order apparent rate constant $\left(\mathrm{s}^{-1}\right)$. The initial transformation rate of BPA is $\mathrm{R}_{\mathrm{BPA}}\left(\mathrm{M} \mathrm{s}^{-1}\right)$ $=\mathrm{k}_{\mathrm{app}} \times[\mathrm{BPA}]_{0}$. Degradation efficiency $(D E)$ of considered system is determined using the following equation:

$D E(\%)=\left[\left(\frac{[B P A]}{[B P A]_{0}}\right)_{R} /\left(\frac{[B P A]}{[B P A]_{0}}\right)_{S}-1\right] \times 100 \%$

where $\left(\frac{[B P A]}{[B P A]_{0}}\right)_{R}$ and $\left(\frac{[B P A]}{[B P A]_{0}}\right)$ are the value of remaining BPA in solution in absence $(\mathrm{R})$ and in the presence $(S)$ of inorganic ion determined experimentally.

Sewage Treatment Plant Water (STPW) is obtained from urban sewage treatment plant of Clermont-Ferrand, France (April $29^{\text {th }}, 2016$ ) and main physico-chemical characteristics are reported in Table 1. STPW is used for photochemical experiments immediately after PTFE $(0.45 \mu \mathrm{m}$ size pore) filtration in order to avoid bacteriological and chemical modifications. All experiments are performed in triplicates in order to ensure the reliability of the results.

\subsection{Laser flash photolysis}

The laser flash photolysis apparatus has been previously described [36] and a brief description of radical species detection is given in this section. The fourth harmonic $\left(\lambda_{\mathrm{exc}}=266 \mathrm{~nm}\right)$ of a Nd:YAG laser is used for the excitation ( the energy of pulse is $40 \mathrm{~mJ}$ ). An appropriate volume of chemical stock solutions (BPA, $\mathrm{S}_{2} \mathrm{O}_{8}{ }^{2-}, \mathrm{H}_{2} \mathrm{O}_{2}, \mathrm{HCO}_{3}{ }^{-} / \mathrm{CO}_{3}{ }^{2-}, \mathrm{Cl}^{-}$and STPW) is mixed just before each experiment to obtain the desired mixtures and concentrations. All experiments are performed at ambient temperature $(293 \pm 2 \mathrm{~K})$ and in aerated solutions. Hydroxyl radical $\left(\mathrm{HO}^{\bullet}\right)$ reactivity is 
determined by using chemical competition kinetics with thiocyanate anion $\left(\mathrm{SCN}^{-}\right)$and di-thyociante radical anion $\left(\mathrm{SCN}_{2}{ }^{\bullet-}\right)$ specie, and the detection wavelength of $\mathrm{SCN}_{2}{ }^{\bullet-}$ was at $470 \mathrm{~nm}$. Sulfate radical anion $\left(\mathrm{SO}_{4}{ }^{\bullet-}\right)$ decay is followed at $450 \mathrm{~nm}$ corresponding to the maximum absorption of this species [37]. Dichlorine radical anion $\left(\mathrm{Cl}_{2}{ }^{\bullet-}\right)$ and carbonate radical anion $\left(\mathrm{CO}_{3}{ }^{\bullet-}\right)$ species are generated using electron transfer reaction between photogenerated sulfate radical and chloride/carbonate ions. The same approach has been previously used to generate $\mathrm{Cl}_{2}{ }^{\bullet-}$ in solution and follow the reactivity toward organic molecules [38]. Details concerning the second order rate constant determinations are reported in Figure SM2. The second order rate constant between selected radicals $\left(\mathrm{SO}_{4}{ }^{\bullet-}, \mathrm{Cl}_{2}{ }^{\bullet-}\right.$ and $\left.\mathrm{CO}_{3}{ }^{\bullet-}\right)$ and BPA or STPW is determined from the regression lines of the logarithmic decays of radical transient (monitored at $450 \mathrm{~nm}, 340 \mathrm{~nm}$ and $600 \mathrm{~nm}$ respectively) as a function of the quencher concentration (for BPA) or normalised for the carbon concentration (for STPW). Each value is the average of 4 consecutive laser pulses and the reported error is $\pm 3 \sigma$, obtained from the scattering of the experimental data from the fitting line.

\subsection{Kinetic modelling}

A kinetic modelling approach is used to estimate the radical species formation during irradiation time in the presence of chloride ions. Table SM1 shows the chemical reactions considered for kinetic modelling (reactions are reported from M1 to M21). The pseudo-first order decay and second-order rate constants are obtained from the literature or experimentally (see results and discussion section). The numerical differential equations of the reaction rates are integrated using 
the ode15s solver function of Matlab. The initial species concentration is implemented in the m-file as the input data. Pseudo-first order constant for the formation of hydroxyl and sulfate radicals $\left(\mathrm{k}_{1}\right.$ and $\mathrm{k}_{2}$ ) are determined under adopted photochemical conditions (irradiance and initial precursor concentrations of $2 \mathrm{mM})$.

\section{Results and discussion}

\subsection{Comparison of UVA/B activation of $\mathrm{H}_{2} \mathrm{O}_{2}$ and $\mathrm{S}_{2} \mathrm{O}_{8}{ }^{2-}$}

In Figure 1 the disappearance of $43.8 \mu \mathrm{M}$ BPA (expressed as [BPA]/[BPA $]_{0}$ ) is followed when 2 $\mathrm{mM}$ of $\mathrm{H}_{2} \mathrm{O}_{2}$ and $\mathrm{S}_{2} \mathrm{O}_{8}{ }^{2-}$ are irradiated using UVA/B using phosphate buffered and unbuffered solutions at $\mathrm{pH} 8.0$ (which is representative of STPW $\mathrm{pH}$ value). Despite no direct photolysis of BPA is observed in pure water (milli-Q), in the presence of persulfate, the degradation rate results to be faster than in the presence of hydrogen peroxide. Such degradation was not observed under dark condition (direct oxidation) indicating that hydrogen peroxide and persulfate can be photochemically activated leading to the degradation of BPA through formation of highly oxidative radical species. In UVA/B- $\mathrm{H}_{2} \mathrm{O}_{2}$ system, the faster $\mathrm{BPA}$ degradation observed at $\mathrm{pH} 8.0$ without buffer can be explained considering the change of $\mathrm{pH}$ value during irradiation. In fact, the solution $\mathrm{pH}$ slowly decreases up to $\mathrm{pH} 6.4$ at the end of the experiment. This modification is correlated to the radical efficiency oxidation increase as reported in Figure SM3 (BPA degradation rate $\left(\mathrm{R}_{\mathrm{BPA}}\right)$ increases from $\sim 1.2 \times 10^{-9} \mathrm{M} \mathrm{s}^{-1}$ at $\mathrm{pH} 10$ to $\sim 5.3 \times 10^{-9} \mathrm{M} \mathrm{s}^{-1}$ at $\left.\mathrm{pH} 4.6\right)$. In fact, it has been reported that the standard redox potential of $\mathrm{HO}^{\bullet}$ in acidic $\mathrm{pH}$ is about $2.4-2.7 \mathrm{eV}$ which is higher 
than that in alkaline $\mathrm{pH}(1.9-2.0 \mathrm{eV})$ [39]. On the contrary, in the UVA/B- $\mathrm{S}_{2} \mathrm{O}_{8}{ }^{2-}$ system, where sulfate radical are generated, a similar value for the BPA degradation rate is found between 4.6 and $9.0\left(\sim 8 \times 10^{-9} \mathrm{M} \mathrm{s}^{-1}\right)$. Such effect can be explained considering that persulfate radical redox potential does not depend on the $\mathrm{pH}$ [40]. Concerning the possible effect of phosphate buffer constituents, the bimolecular rate constants between photogenerated hydroxyl or sulfate radicals and $\mathrm{HPO}_{4}{ }^{2-} / \mathrm{H}_{2} \mathrm{PO}_{4}{ }^{-}$are $\leq 10^{6} \mathrm{M}^{-1} \mathrm{~s}^{-1}$ [41] so we can argue that the quenching effect of buffer could be negligible under adopted experimental conditions.

\subsection{Effect of chloride ions}

\subsubsection{UVA/B- $\mathrm{H}_{2} \mathrm{O}_{2}$ system}

In Figure 2, the effect of chloride ions on the BPA degradation efficiency using $2 \mathrm{mM}$ of $\mathrm{H}_{2} \mathrm{O}_{2}$ is investigated at $\mathrm{pH} 4.6$ and 8.0 under irradiation. At pH 8.0, slight inhibition of chloride ions (from 2 to $10 \mathrm{mM}$ ) is observed compared to the degradation using hydrogen peroxide alone (increasing the chloride ion concentration up to $100 \mathrm{mM}$ the inhibition reaches $\sim 15 \%$ ). However, the detrimental effect of chloride ions is more marked at $\mathrm{pH} 4.6$ where the BPA removal efficiency strongly decreases in the presence of $5 \mathrm{mM} \mathrm{Cl}^{-}$. The different BPA degradation trend at $\mathrm{pH} 8.0$ and 4.6 can be justified considering that photogenerated hydroxyl radicals are in equilibrium with $\mathrm{ClOH}^{\bullet-}$ specie in the presence of chloride ions (R1 and see reaction M13 in table SM1 for reactivity constant value) leading to the formation of $\mathrm{Cl}^{\bullet}$ only in acidic media (R2).

$\mathrm{HO}^{\bullet}+\mathrm{Cl}^{-} \rightleftarrows \mathrm{ClOH}^{\bullet-}$ 
$\mathrm{ClOH}^{\bullet-}+\mathrm{H}^{+} \rightleftarrows \mathrm{Cl}^{\bullet}+\mathrm{H}_{2} \mathrm{O} \quad(\mathrm{R} 2)$

On the other hand, at pH 8.0 only a negligible amount of hydroxyl radical are expected to be finally converted into $\mathrm{Cl}^{\bullet}$ compared to $\mathrm{pH} 4.6$.

The effect of chloride ions on the radical species formation can be partially predicted using the chemical kinetic modelling approach that estimates a negligible effect of $\mathrm{Cl}^{-}$on the hydroxyl radical formation rate at $\mathrm{pH}$ 8.0. Despite no significant inhibition of chloride ions on the hydroxyl radical concentration (the initial concentration of $\mathrm{HO}^{\bullet}$ decreases from $\sim 4.1 \times 10^{-13} \mathrm{M}$ to $\sim 3.9 \times 10^{-13} \mathrm{M}$ in the presence of $5 \mathrm{mM}$ of $\mathrm{Cl}^{-}$at $\mathrm{pH} 4.6$ as reported in Fig. SM4), the amount of chlorine radical species such as $\mathrm{Cl}^{\bullet}, \mathrm{Cl}_{2}{ }^{--}$and $\mathrm{ClOH}^{\bullet-}$ is strongly enhanced (Fig. SM5). In fact, the kinetic model predicts that $\mathrm{Cl}_{2}^{\bullet-}$, which is about 2 times less reactive toward BPA than $\mathrm{HO}^{\bullet}$, is the main specie present in solution (see Table 2) explaining the inhibition of BPA degradation when $5 \mathrm{mM}$ of chloride ions are mixed to $\mathrm{H}_{2} \mathrm{O}_{2}$.

\subsection{2 $\mathrm{UVA} / \mathrm{B}-\mathrm{S}_{2} \mathrm{O}_{8}{ }^{2-}$ system}

The BPA degradation using UVA/B- $\mathrm{S}_{2} \mathrm{O}_{8}{ }^{2-}$ system is found to be strongly influenced by chloride ions (Fig. SM6). Two contrasting effects can be observed increasing the chloride ion concentration: the first (from 0 to $2 \mathrm{mM}$ of $\mathrm{Cl}^{-}$) is the drastic decrease (up to $80 \%$ ) of the degradation efficiency (DE), whereas the second $\left(\left[\mathrm{Cl}^{-}\right]>2 \mathrm{mM}\right)$ is a positive effect up to the enhancement of BPA degradation observed in the presence of 100 and $200 \mathrm{mM}$ of $\mathrm{Cl}^{-}$(Fig. 3). This opposite trend (inhibition and enhancement) is investigated considering the radical species generation as a function 
of chloride ions concentration and their reactivity with photogenerated sulfate radical. Without chloride, sulfate radicals are able to oxidize water and hydroxide ions leading to the formation of hydroxyl radical in solution (see reactions M3 and M4 in Table SM1). Considering the second order rate constant of these two reactions, we can argue that less than $0.4 \%$ of sulfate radical are converted into hydroxyl radical (mainly through reaction M3). The kinetic model, considering the photolysis rate of persulfate obtained experimentally (Fig. SM7 and SM8), estimates a steady state concentration of sulfate and hydroxyl radicals $\left(\left[\mathrm{SO}_{4}{ }^{\bullet-}\right]_{\mathrm{ss}}\right.$ and $\left.\left[\mathrm{HO}^{\bullet}\right]_{\mathrm{ss}}\right)$ of $1.5 \times 10^{-10}$ and $4.6 \times 10^{-12}$ $\mathrm{M}$ whene $2 \mathrm{mM}$ of persulfate are irradiate using UVA/B radiation at $\mathrm{pH} 8.0$ (Fig. 4). The presence of $2 \mathrm{mM}$ of chloride ions is able to scavenge about $66 \%$ of sulfate radicals leading to the formation of $\mathrm{Cl}^{\bullet}$ which is a source of other radical species such as $\mathrm{Cl}_{2}{ }^{\bullet-}$ and $\mathrm{ClOH}^{\bullet-}$ through a more complex reaction system (M13 to M15). Increasing the chloride ions concentration, despite no effect observed on the hydroxyl radical steady-state concentration, sulfate radical concentration decreases of about 2 order of magnitude (from $10^{-12}$ to $10^{-14} \mathrm{M}$ ). This trend can be explained considering that sulfate radical are able to oxidize chloride ions into chlorine radicals (M16) that can be responsible for the BPA degradation increase observed at high chloride ions concentrations. For instance, the reactivity of $\mathrm{Cl}^{\bullet}$ with phenol has been estimated to be $2.5 \times 10^{10} \mathrm{M} \mathrm{s}^{-1}$ [42]. BPA degradation enhancement observed when persulfate are irradiated in the presence of chloride ions can be also explained considering the formation of new reactive species (that are not considered by our kinetic model) such as hypochlorous acid/hypochlorite ions $\left(\mathrm{HOCl} / \mathrm{OCl}^{-} \mathrm{pka}=7.5\right)$ as suggested by Yuan and co-workers [43]. Chlorine active species are responsible for direct oxidation of organic 
molecules or represent a photochemical source of hydroxyl and chlorine radical under UV radiation $[44,45]$.

\subsection{Effect of $\mathrm{HCO}_{3}{ }^{-} / \mathrm{CO}_{3}{ }^{2-}$}

The effect of carbonates $\left(\mathrm{HCO}_{3}{ }^{-} / \mathrm{CO}_{3}{ }^{2-} \mathrm{pka}=10.33\right)$ is investigated for UVA/B activation of $\mathrm{H}_{2} \mathrm{O}_{2}$ and $\mathrm{S}_{2} \mathrm{O}_{8}{ }^{2-}$ at $\mathrm{pH} 8.0$ and $\mathrm{pH} 9.0$ using buffer solutions (see Figure SM9). The presence of $5 \mathrm{mM}$ of carbonates at $\mathrm{pH} 8.0$ in $\mathrm{UV}-\mathrm{H}_{2} \mathrm{O}_{2}$ system inhibits about $50 \%$ of the BPA degradation (the pseudo first order decay decreases from $5.3 \times 10^{-5} \mathrm{~s}^{-1}$ to $2.6 \times 10^{-5} \mathrm{~s}^{-1}$ ) while the effect on the $\mathrm{UV}-\mathrm{S}_{2} \mathrm{O}_{8}{ }^{2-}$ system is estimate to be around $18 \%$ (the pseudo first order decay decreases from $1.9 \times 10^{-4} \mathrm{~s}^{-1}$ to $\left.1.5 \times 10^{-4} \mathrm{~s}^{-1}\right)$

The scavenging effect of carbonates on photo-activation of hydrogen peroxide and persulfate can be predicted considering the reactivity of hydroxyl and sulfate radicals toward $\mathrm{HCO}_{3}{ }^{-} / \mathrm{CO}_{3}{ }^{2}$ $\left(k_{\mathrm{HO}^{\bullet}, \mathrm{HCO}_{3}^{-}}=8.6 \times 10^{6} \mathrm{M}^{-1} \mathrm{~s}^{-1}, \quad k_{\mathrm{SO}_{4}^{--}, \mathrm{HCO}_{3}^{-}}=2.8 \times 10^{6} \mathrm{M}^{-1} \mathrm{~s}^{-1} \quad, \quad k_{\mathrm{HO}^{\bullet}, \mathrm{CO}_{3}^{2-}}=3.5 \times 10^{8} \mathrm{M}^{-1} \mathrm{~s}^{-1}\right.$ ， $k_{\mathrm{SO}_{4}^{--}, \mathrm{CO}_{3}^{2-}}=6.1 \times 10^{6} \mathrm{M}^{-1} \mathrm{~s}^{-1}$ ) $[21,46]$ and BPA determined by laser flash photolysis experiments (see Table 2). In Figure 5 the inhibition of the reactivity toward BPA due to the presence of $\mathrm{HCO}_{3}{ }^{-} / \mathrm{CO}_{3}{ }^{2}$ is estimated as the ratio between the pseudo-first order decays of considered radicals with carbonates and BPA $\left(\frac{k_{\text {Carbonates }}^{\prime}}{k_{B P A}^{\prime}+k_{\text {Carbonates }}^{\prime}} \times 100\right)$ as a function of carbonates concentration and $\mathrm{pH}$. It is interesting to observe that, while for sulfate radical the inhibition is not affected by the $\mathrm{pH}$ of the solution, for hydroxyl radical a negative effect is correlated to the $\mathrm{pH}$ increase. In fact, after $\mathrm{pH} \sim 8.2$ 
we expect the presence of $\mathrm{CO}_{3}{ }^{2-}$ species, which have higher reactivity toward hydroxyl radical (at pH $9.5 \sim 13 \%$ of $\mathrm{CO}_{3}{ }^{2-}$ and $87 \%$ of $\mathrm{HCO}_{3}{ }^{-}$are present in solution).

However, generated carbonate radicals are expected to react with BPA partially counterbalancing the sink of hydroxyl and sulfate radicals. Interestingly, degradation profiles of BPA at $\mathrm{pH} 9.0$ comparted to the $\mathrm{pH} 8.0$ (see Figure SM9) show a less pronounced negative effect of carbonates on the inhibition of BPA degradation. Such effect can be explained considering the reactivity between $\mathrm{CO}_{3}{ }^{\bullet-}$ and phenol/phenolate groups. Moore and co-workers reported that reactivity of $\mathrm{CO}_{3}{ }^{\bullet-}$ with phenolate is about 6 times higher than the value measured for phenol $\left(k_{C O_{3}^{-}, \text {Phenol }}=3.9 \times 10^{8} M^{-1} s^{-1}\right.$ and $\left.k_{\mathrm{CO}_{3}^{-}, \text {Phenolate }}=2.4 \times 10^{9} \mathrm{M}^{-1} \mathrm{~s}^{-1}\right)$ [47]. We can reasonably expect a similar trend for BPA where increasing formation of carbonate radical at higher $\mathrm{pH}$ can enhance degradation of target pollutant in water.

\subsection{Transformation products identification}

Different experiments are conducted using BPA concentration of $43.8 \mu \mathrm{M}$ in the presence of $i$ ) hydrogen peroxide $(2 \mathrm{mM}), i i)$ hydrogen peroxide $(2 \mathrm{mM})+$ chloride ions $(100 \mathrm{mM})$, iii) persulfate $(2 \mathrm{mM})$ and $i v)$ persulfate $(2 \mathrm{mM})+$ chloride ions $(100 \mathrm{mM})$. Table SM2 summarizes the chemical structures of transformation products identified using HPLC-MS (negative mode) and GC-MS on the basis of molecular peak, fragmentation and literature data.

Interestingly, hydroxylated BPA products are mainly found by HPLC-MS indicating that first reaction step of sulfate and hydroxyl radicals is the hydrogen abstraction on the aromatic ring and 
consequent water addition. Sharma et al. investigated the intermediates of BPA degradation using UVC-peroxymonosulfate system and considered that hydrogen abstraction is not the only process occurring, but one of the most important initial steps of BPA degradation [48]. The authors concluded that BPA is oxidized by $\mathrm{SO}_{4}{ }^{\bullet-}$ through electron transfer and then $\mathrm{H}$ abstraction generates a hydroxyl BPA radical. Similar transformation products are found in all conditions with aromatic ring scission derivatives, which are also normally found in BPA degradation pathway induced by $\mathrm{HO}^{\bullet}$ or $\mathrm{SO}_{4}{ }^{\bullet-}$ attack [49-51]. However, a chlorinated BPA product is detected only using $\mathrm{UVA} / \mathrm{B}-\mathrm{S}_{2} \mathrm{O}_{8}{ }^{2-}$ in the presence of chloride ions. Chlorinated derivatives have been previously detected by Zafra et al using chlorination experiments [52] corroborating the hypothesis that reactivity of sulfate radical can lead, in the presence of chloride ions, to the formation of new species such as $\mathrm{HOCl} / \mathrm{OCl}^{-}$that are expected to directly oxidize BPA in solution. The formation of chlorinated derivative reasonably suggests that the presence of high $\mathrm{Cl}^{-}$concentration would change the pathway of BPA degradation in the presence of sulfate radical, while this phenomenon is not observed in UVA/B- $\mathrm{H}_{2} \mathrm{O}_{2}$ system. Moreover, high mass values are found in HPLC-MS $(\mathrm{m} / \mathrm{z}=453)$ in the presence of sulfate radical anions suggesting the formation of dimeric molecules produced via radical-radical recombination.

\subsection{BPA degradation in STPW}

To test the feasibility and performances of UVA/B activation of hydrogen peroxide and persulfate in simulated treatment systems, STPW are spiked with $4.3 \mu \mathrm{M}$ and $430 \mathrm{nM}$ of BPA $\left(1\right.$ and $0.1 \mathrm{mg} \mathrm{L}^{-1}$ 
respectively) before irradiation in the presence of $2 \mathrm{mM}$ of radical precursors. Due to the complexity of the STPW matrix, the inhibition effect of naturally constituents is investigated through several experiments. First, the degradation of BPA is carried out in STPW previously acidified using $\mathrm{HClO}_{4}$ to $\mathrm{pH}<3$ in order to remove inorganic carbon (i.e. carbonate ions), and then basified back to $\mathrm{pH}$ around 8 (indicated above as STPW*). The purpose of this experiment is to discriminate the effect of organic and inorganic carbon on the degradation efficiency of considered system. These experiments show that the degradation of BPA in STPW and STPW* is almost the same; only a slight BPA inhibition (less than 5\%) is observed in the presence of persulfate indicating a negligible effect of inorganic carbon (i.e. carbonates) on the degradation treatment efficiency (Fig. 6). Since the concentration of inorganic carbon is $4.16 \mathrm{mM}$ in our STPW, it could be concluded that in this concentration level the degradation of organic compound is almost not affected by inorganic carbon. This trend can be also investigated considering the reactivity constant determined between hydroxyl and sulfate radicals and STPW normalizing the value to the carbon concentration (organic and inorganic). In Table 2 it is interesting to observe that reactivity constants using not modified STPW are about two times for hydroxyl radical and three times for sulfate radical lower than those determined after inorganic carbon removal (i.e. STPW*).

Considering the second order rate constant between hydroxyl radical and sulfate radical anion with STPW matrix, $\mathrm{HCO}_{3}{ }^{-}$(the main species present at $\mathrm{pH}$ 8.0) and BPA reported in this study (see Table 2), it is possible to investigate the formation pathways of photogenerated radicals in solution. For this purpose we considered that hydroxyl radicals (or sulfate radicals) can react with STPW 
constituents or BPA in solution.

In the system UVA/B- $\mathrm{H}_{2} \mathrm{O}_{2}$, we can argue that about $98.4 \%$ of hydroxyl radicals react with constituents of STPW (16.6\% of which accounted for by carbonates) while $1.6 \%$ directly with BPA (Table 3). In the system UVA/B- $\mathrm{S}_{2} \mathrm{O}_{8}{ }^{2-}$ about $99.8 \%$ of the sulfate radical reactivity is attributed to the STPW constituents, while only $0.2 \%$ is accounted by for BPA (Table 3). However, the BPA degradation results to be faster in the system $\mathrm{UVA} / \mathrm{B}-\mathrm{S}_{2} \mathrm{O}_{8}{ }^{2-}$ (Fig. 6).

The high efficiency degradation using UVA/B- $\mathrm{S}_{2} \mathrm{O}_{8}{ }^{2-}$ system could be explained considering that about $72 \%$ of sulfate radicals react with chloride ions leading to the formation of chlorine radical which is a secondary source of hydroxyl radical and other chlorine reactive species in alkaline media. In order to assess the occurring reactive involvement using UVA/B- $\mathrm{S}_{2} \mathrm{O}_{8}{ }^{2-}$ process, a new experiment is performed spiking the solution with specific radical scavengers. STPW is spiked with $4.3 \mu \mathrm{M}$ of BPA in the presence of 2-propanol (2-Pr) which is able to scavenge hydroxyl radical and sulfate radical $\left(k_{H O^{*}, 2-\mathrm{Pr}}=1.9 \times 10^{9} M^{-1} s^{-1}, \quad k_{S O_{4}^{-}, 2-\mathrm{Pr}}=8.2 \times 10^{7} M^{-1} s^{-1}\right)$ and tert-butanol $(t$-But $)$ which is more selective scavenger of hydroxyl radical $\left(k_{H O^{*}, t \text {-But }}=3.1 \times 10^{9} M^{-1} s^{-1}\right.$, $\left.k_{S O_{4}^{-}, t-\text { But }}=8.4 \times 10^{5} M^{-1} s^{-1}\right)[46,53]$. In the presence of $50 \mathrm{mM}$ of $t$-But the degradation rate is inhibited of $\sim 50 \%$, while, using 2-Pr, only 5\% of BPA degradation is observed (Fig. 7). This result confirms that a significant fraction of sulfate radicals are converted into hydroxyl radical in STPW through a complex mechanism. In fact, chlorine radical can be converted into $\mathrm{ClOH}^{\bullet-}(\mathrm{R} 3$ and R4) which leads to the formation of hydroxyl radical in solution at $\mathrm{pH} 8.0$ (see reaction $\mathrm{R} 1$ ).

$\mathrm{Cl}^{\bullet}+\mathrm{H}_{2} \mathrm{O} \rightarrow \mathrm{ClOH}^{\bullet-}+\mathrm{H}^{+}$ 
$\mathrm{Cl}^{\bullet}+\mathrm{HO}^{-} \rightarrow \mathrm{ClOH}^{\bullet-}$

Moreover, our conclusion are confirmed considering the high scavenging efficiency of 2-Pr and $t$-But on chlorine radical $\left(k_{C l^{*}, 2-\mathrm{Pr}}=6.0 \times 10^{9} M^{-1} s^{-1}\right.$ and $\left.k_{C l^{*}, t-B u t}=6.2 \times 10^{9} M^{-1} s^{-1}\right)[54,55]$.

\section{Conclusion}

In this paper UV fraction of solar light (UVA/B) is used to efficiently activate hydrogen peroxide and persulfate leading to the degradation of BPA, adopted as pollutant model, in simulated and real STPW. A strong effect of chloride ions is observed on the UVA/B- $\mathrm{S}_{2} \mathrm{O}_{8}{ }^{2-}$ system where photogenerated sulfate radicals can lead to the formation of reactive species such as hydroxyl, chlorine and dichlorine radical anions and probably $\mathrm{HOCl} / \mathrm{OCl}^{-}$. In fact, at high chloride ions concentration an increase of BPA removal was observed.

In the presence $\mathrm{H}_{2} \mathrm{O}_{2}$, carbonate ions strongly inhibit the efficiency of BPA degradation, while, this effect, is less pronounced using UVA/B- $\mathrm{S}_{2} \mathrm{O}_{8}{ }^{2-}$. In STPW matrix the presence of Dissolved Organic Matter (DOM) represents the main radical scavenger; however, this negative effect can be counterbalanced by chloride ions using UVA/B- $\mathrm{S}_{2} \mathrm{O}_{8}{ }^{2-}$.

These results are encouraging for future application of solar activation of persulfate for pollutant removal in STPW containing high chloride ions concentrations. Moreover, the use of chemical kinetic approach improves the oxidant capacity estimation of advanced oxidation process as function of water chemical composition. 


\section{Acknowledgements}

This work was partially supported by Natural Science Foundation of China (No. 21367003) and Guangxi Natural Science Foundation (No. 2014GXNSFBA118217). We also gratefully acknowledge the Haina Project of Guangxi University for providing financial support for W.H. to stay at the Clermont Auvergne University in Clermont-Ferrand, France. Authors acknowledge financial support from the Region Council of Auvergne, from the "Féderation des Recherches en Environnement" through the CPER "Environment" founded by the Region Auvergne, the French government, FEDER from the European Community and PRC program CNRS/NSFC n 270437. 


\section{References}

[1] X. He, G. Zhang, A.A. de la Cruz, K.E. O'Shea, D.D. Dionysiou, Degradation mechanism of cyanobacterial toxin cylindrospermopsin by hydroxyl radicals in homogeneous $\mathrm{UV} / \mathrm{H}_{2} \mathrm{O}_{2}$ process, Environ. Sci. Technol., 48 (2014) 4495-4504.

[2] J. Saien, M. Osali, A.R. Soleymani, UV/persulfate and UV/hydrogen peroxide processes for the treatment of salicylic acid: effect of operating parameters, kinetic, and energy consumption, Desalin. Water Treat., 56 (2015) 3087-3095.

[3] P. Xie, J. Ma, W. Liu, J. Zou, S. Yue, X. Li, M.R. Wiesner, J. Fang, Removal of 2-MIB and geosmin using UV/persulfate: Contributions of hydroxyl and sulfate radicals, Water Res., 69 (2015) 223-233.

[4] W. Yang, H. Zhou, N. Cicek, Treatment of organic micropollutants in water and wastewater by UV-based processes: A literature review, Crit. Rev. Env. Sci. Tec., 44 (2014) 1443-1476.

[5] S.-H. Yoon, S. Jeong, S. Lee, Oxidation of bisphenol A by UV/ $\mathrm{S}_{2} \mathrm{O}_{8}{ }^{2-}$ : Comparison with UV/ $\mathrm{H}_{2} \mathrm{O}_{2}$, Environ. Technol., 33 (2012) 123-128.

[6] S.E. Beck, H. Ryu, L.A. Boczek, J.L. Cashdollar, K.M. Jeanis, J.S. Rosenblum, O.R. Lawal, K.G. Linden, Evaluating UV-C LED disinfection performance and investigating potential dual-wavelength synergy, Water Res., 109 (2017) $207-216$.

[7] Y. Wu, A. Bianco, M. Brigante, W. Dong, P. de Sainte-Claire, K. Hanna, G. Mailhot, Sulfate radical photogeneration using Fe-EDDS: Influence of critical parameters and naturally occurring scavengers, Environ. Sci. Technol., 49 (2015) 14343-14349.

[8] B.M. Souza, M.W.C. Dezotti, R.A.R. Boaventura, V.J.P. Vilar, Intensification of a solar photo-Fenton reaction at near neutral $\mathrm{pH}$ with ferrioxalate complexes: A case study on diclofenac removal from aqueous solutions, Chem. Eng. J., 256 (2014) 448-457.

[9] L. Zhao, Y. Ji, D. Kong, J. Lu, Q. Zhou, X. Yin, Simultaneous removal of bisphenol A and phosphate in zero-valent iron activated persulfate oxidation process, Chem. Eng. J., 303 (2016) 458-466.

[10] C. Zhu, G. Fang, D.D. Dionysiou, C. Liu, J. Gao, W. Qin, D. Zhou, Efficient transformation of DDTs with Persulfate Activation by Zero-valent Iron Nanoparticles: A Mechanistic Study, J. Hazard. Mater., 316 (2016) 232-241.

[11] D. Xia, R. Yin, J. Sun, T. An, G. Li, W. Wang, H. Zhao, P.K. Wong, Natural magnetic pyrrhotite as a high-Efficient persulfate activator for micropollutants degradation: Radicals identification and toxicity evaluation, J. Hazard. Mater., 340 (2017) 435-444.

[12] P. Polczynski, R. Jurczakowski, W. Grochala, Stabilization and strong oxidizing properties of $\mathrm{Ag}$ (ii) in a fluorine-free solvent, Chem. Commun., 49 (2013) 7480-7482.

[13] J. Wang, S. Wang, Activation of persulfate (PS) and peroxymonosulfate (PMS) and application for the degradation of emerging contaminants, Chem. Eng. J., 334 (2018) 1502-1517.

[14] L.R. Bennedsen, J. Muff, E.G. Søgaard, Influence of chloride and carbonates on the reactivity of activated persulfate, Chemosphere, 86 (2012) 1092-1097.

[15] Y. Liu, X. He, X. Duan, Y. Fu, D. Fatta-Kassinos, D.D. Dionysiou, Significant role of UV and carbonate radical on the degradation of oxytetracycline in UV-AOPs: Kinetics and mechanism, Water Res., 95 (2016) 195-204.

[16] Y. Yang, J.J. Pignatello, J. Ma, W.A. Mitch, Comparison of halide impacts on the efficiency of contaminant degradation by sulfate and hydroxyl radical-based advanced oxidation processes (AOPs), Environ. Sci. Technol., 48 (2014) 2344-2351. 
[17] A. Afzal, P. Drzewicz, J.W. Martin, M. Gamal El-Din, Decomposition of cyclohexanoic acid by the UV/ $\mathrm{H}_{2} \mathrm{O}_{2}$ process under various conditions, Sci. Total Environ., 426 (2012) 387-392.

[18] C. Liang, Z.-S. Wang, N. Mohanty, Influences of carbonate and chloride ions on persulfate oxidation of trichloroethylene at $20^{\circ} \mathrm{C}$, Sci. Total Environ., 370 (2006) 271-277.

[19] K. Mopper, X. Zhou, Hydroxyl radical photoproduction in the sea and its potential impact on marine processes, Science, 250 (1990) 661.

[20] R.E. Huie, C.L. Clifton, Temperature dependence of the rate constants for reactions of the sulfate radical, SO4-, with anions, J. Phys. Chem, 94 (1990) 8561-8567.

[21] R.E. Huie, C.L. Clifton, P. Neta, Electron transfer reaction rates and equilibria of the carbonate and sulfate radical anions, Int. J. Radiat. Appl. Instrum. C Radiat. Phys. Chem., 38 (1991) 477-481.

[22] J. Kiwi, A. Lopez, V. Nadtochenko, Mechanism and kinetics of the $\mathrm{OH}$-radical intervention during Fenton oxidation in the presence of a significant amount of radical scavenger (Cl-), Environ. Sci. Technol., 34 (2000) 2162-2168.

[23] J.E.F. Moraes, F.H. Quina, C.A.O. Nascimento, D.N. Silva, O. Chiavone-Filho, Treatment of saline wastewater contaminated with hydrocarbons by the photo-Fenton process, Environ. Sci. Technol., 38 (2004) 1183-1187.

[24] Y. Yang, J.J. Pignatello, J. Ma, W.A. Mitch, Effect of matrix components on $\mathrm{UV} / \mathrm{H}_{2} \mathrm{O}_{2}$ and $\mathrm{UV} / \mathrm{S}_{2} \mathrm{O}_{8}{ }^{2-}$ advanced oxidation processes for trace organic degradation in reverse osmosis brines from municipal wastewater reuse facilities, Water Res., 89 (2016) 192-200.

[25] G.-D. Fang, D.D. Dionysiou, Y. Wang, S.R. Al-Abed, D.-M. Zhou, Sulfate radical-based degradation of polychlorinated biphenyls: Effects of chloride ion and reaction kinetics, J. Hazard. Mater., 227-228 (2012) 394-401.

[26] G.P. Anipsitakis, D.D. Dionysiou, M.A. Gonzalez, Cobalt-mediated activation of peroxymonosulfate and sulfate radical attack on phenolic compounds. Implications of chloride ions, Environ. Sci. Technol., 40 (2006) 1000-1007.

[27] J. Huang, S.A. Mabury, Steady-state concentrations of carbonate radicals in field waters, Environ. Toxicol. Chem., 19 (2000) 2181-2188.

[28] R. Zhang, P. Sun, T.H. Boyer, L. Zhao, C.-H. Huang, Degradation of pharmaceuticals and metabolite in synthetic human urine by UV, UV/ $\mathrm{H}_{2} \mathrm{O}_{2}$, and UV/PDS, Environ. Sci. Technol., 49 (2015) 3056-3066.

[29] C. Wu, K.G. Linden, Phototransformation of selected organophosphorus pesticides: roles of hydroxyl and carbonate radicals, Water Res., 44 (2010) 3585-3594.

[30] O.S. Keen, K.G. Linden, Degradation of antibiotic activity during $\mathrm{UV} / \mathrm{H}_{2} \mathrm{O}_{2}$ advanced oxidation and photolysis in wastewater effluent, Environ. Sci. Technol., 47 (2013) 13020-13030.

[31] Y. Lee, D. Gerrity, M. Lee, S. Gamage, A. Pisarenko, R.A. Trenholm, S. Canonica, S.A. Snyder, U. Von Gunten, Organic contaminant abatement in reclaimed water by $\mathrm{UV} / \mathrm{H}_{2} \mathrm{O}_{2}$ and a combined process consisting of $\mathrm{O}_{3} / \mathrm{H}_{2} \mathrm{O}_{2}$ followed by $\mathrm{UV} / \mathrm{H}_{2} \mathrm{O}_{2}$ : Prediction of abatement efficiency, energy consumption, and byproduct formation, Environ. Sci. Technol., 50 (2016) 3809-3819.

[32] F.L. Rosario-Ortiz, E.C. Wert, S.A. Snyder, Evaluation of UV/ $\mathrm{H}_{2} \mathrm{O}_{2}$ treatment for the oxidation of pharmaceuticals in wastewater, Water Res., 44 (2010) 1440-1448.

[33] H.-W. Yu, T. Anumol, M. Park, I. Pepper, J. Scheideler, S.A. Snyder, On-line sensor monitoring for chemical contaminant attenuation during $\mathrm{UV} / \mathrm{H}_{2} \mathrm{O}_{2}$ advanced oxidation process, Water Res., 81 (2015) 250-260.

[34] R. Zhang, Y. Yang, C.-H. Huang, N. Li, H. Liu, L. Zhao, P. Sun, UV/ $\mathrm{H}_{2} \mathrm{O}_{2}$ and UV/PDS treatment of trimethoprim and sulfamethoxazole in synthetic human urine: Transformation products and toxicity, Environ. Sci. Technol., 50 (2016) 2573-2583. 
[35] E. Kattel, M. Trapido, N. Dulova, Oxidative degradation of emerging micropollutant acesulfame in aqueous matrices by UVA-induced $\mathrm{H}_{2} \mathrm{O}_{2} / \mathrm{Fe}^{2+}$ and $\mathrm{S}_{2} \mathrm{O}_{8}{ }^{2-} / \mathrm{Fe}^{2+}$ processes, Chemosphere, 171 (2017) 528-536.

[36] M. Brigante, T. Charbouillot, D. Vione, G. Mailhot, Photochemistry of 1-Nitronaphthalene: A potential source of singlet oxygen and radical species in atmospheric waters, J. Phys. Chem. A, 114 (2010) 2830-2836.

[37] E. Hayon, A. Treinin, J. Wilf, Electronic spectra, photochemistry, and autoxidation mechanism of the sulfite-bisulfite-pyrosulfite systems. $\mathrm{SO}_{2}{ }^{-}, \mathrm{SO}_{3}{ }^{-}, \mathrm{SO}_{4}{ }^{-}$, and $\mathrm{SO}_{5}{ }^{-}$radicals, J. Am. Chem. Soc., 94 (1972) 47-57.

[38] Y. Wu, R. Prulho, M. Brigante, W. Dong, K. Hanna, G. Mailhot, Activation of persulfate by Fe(III) species: Implications for 4-tert-butylphenol degradation, J. Hazard. Mater., 322, Part B (2017) 380-386.

[39] P. Wardman, Reduction potentials of one - electron couples involving free radicals in aqueous solution, J. Phys. Chem. Ref. Data, 18 (1989) 1637-1755.

[40] P. Neta, R.E. Huie, A.B. Ross, Rate constants for reactions of inorganic radicals in aqueous solution, J. Phys. Chem. Ref. Data, 17 (1988) 1027-1284.

[41] P. Maruthamuthu, P. Neta, Phosphate radicals. Spectra, acid-base equilibriums, and reactions with inorganic compounds, J. Phys. Chem. A, 82 (1978) 710-713.

[42] Z.B. Alfassi, S. Mosseri, P. Neta, Reactivities of chlorine atoms and peroxyl radicals formed in the radiolysis of dichloromethane, J. Phys. Chem., 93 (1989) 1380-1385.

[43] R. Yuan, S.N. Ramjaun, Z. Wang, J. Liu, Effects of chloride ion on degradation of Acid Orange 7 by sulfate radical-based advanced oxidation process: Implications for formation of chlorinated aromatic compounds, J. Hazard. Mater., 196 (2011) 173-179.

[44] M.J. Watts, K.G. Linden, Chlorine photolysis and subsequent $\mathrm{OH}$ radical production during UV treatment of chlorinated water, Water Res., 41 (2007) 2871-2878.

[45] M. Deborde, U. von Gunten, Reactions of chlorine with inorganic and organic compounds during water treatment-Kinetics and mechanisms: A critical review, Water Res., 42 (2008) 13-51.

[46] G.V. Buxton, C.L. Greenstock, W.P. Helman, A.B. Ross, Critical review of rate constants for reactions of hydrated electrons, hydrogen atoms and hydroxyl radicals (OH/O-) in aqueous solution, J. Phys. Chem. Ref. Data, 17 (1988) 513-886.

[47] J.S. Moore, G.O. Phillips, A. Sosnowski, Reaction of the carbonate radical anion with substituted phenols, Int. J. Radiat. Biol. Relat. Stud. Phys. Chem. Med., 31 (1977) 603-605.

[48] J. Sharma, I.M. Mishra, D.D. Dionysiou, V. Kumar, Oxidative removal of Bisphenol A by UV-C/peroxymonosulfate (PMS): Kinetics, influence of co-existing chemicals and degradation pathway, Chem. Eng. J., 276 (2015) 193-204.

[49] W. Huang, M. Luo, C. Wei, Y. Wang, K. Hanna, G. Mailhot, Enhanced heterogeneous photo-Fenton process modified by magnetite and EDDS: BPA degradation, Environ. Sci. Poll. Res., 24 (2017) 10421-10429.

[50] H. Katsumata, S. Kawabe, S. Kaneco, T. Suzuki, K. Ohta, Degradation of bisphenol A in water by the photo-Fenton reaction, J. Photochem. Photobiol., A, 162 (2004) 297-305.

[51] E.J. Rosenfeldt, K.G. Linden, Degradation of Endocrine Disrupting Chemicals Bisphenol A, Ethinyl Estradiol, and Estradiol during UV Photolysis and Advanced Oxidation Processes, Environ. Sci. Technol., 38 (2004) 5476-5483.

[52] A. Zafra, M. del Olmo, B. Suárez, E. Hontoria, A. Navalón, J.L.s. Vílchez, Gas chromatographic-mass spectrometric method for the determination of bisphenol A and its chlorinated derivatives in urban wastewater, Water Res., 37 (2003) 735-742.

[53] C.L. Clifton, R.E. Huie, Rate constants for hydrogen abstraction reactions of the sulfate radical, SO4-. Alcohols, Int. 
J. Chem. Kinet., 21 (1989) 677-687.

[54] R. Mertens, C. von Sonntag, Photolysis $(\lambda=254 \mathrm{~nm})$ of tetrachloroethene in aqueous solutions, J. Photochem. Photobiol., A, 85 (1995) 1-9.

[55] S. Takashi, M. Kazuhiro, H. Hiroyuki, K. Meiseki, On the reactivity of chlorine atoms towards alcohols, Chem. Lett., 16 (1987) 1429-1430. 
Table 1 : pH, main anions concentrations and TOC determined for STPW used in this work.

\begin{tabular}{|l|l|l|l|l|l|}
\hline $\mathbf{p H}$ & {$\left[\mathbf{C l}^{-}\right](\mathrm{mM})$} & {$\left[\mathbf{H C O}_{\mathbf{3}}{ }^{-}\right] /\left[\mathbf{C O}_{\mathbf{3}}{ }^{2-}\right](\mathrm{mM})$} & {$\left[\mathbf{S O}_{\mathbf{4}}{ }^{2-}\right](\mu \mathrm{M})$} & {$\left[\mathbf{N O}_{\mathbf{3}}{ }^{-}\right](\mu \mathrm{M})$} & {$[\mathbf{T O C}]\left(\mathrm{mgC} \mathrm{L}^{-1}\right)$} \\
\hline 7.9 & 2.58 & $4.16\left(50 \mathrm{mgC} \mathrm{L}^{-1}\right)$ & 54 & 12.3 & 27.2 \\
\hline
\end{tabular}

Table 2 : Second order rate constant determined for BPA and STPW before and after carbonates removal. STPW indicated Sewage Treatment Plan water without chemical modification while STPW $^{*}$ is STPW after removal of carbonates (see materials and methods). Second order rate constants are normalized for the number of all carbons (organic and inorganic). Errors are estimated to $\pm 3 \sigma$, which was obtained from the scattering of the experimental data from the fitting line

\begin{tabular}{|l|l|l|l|l|}
\hline & $k_{\mathrm{HO}}$ & $k_{\mathrm{SO}_{4}^{-}}$ & $k_{C l_{2}^{-}}$ & $k_{C O_{3}^{-}}$ \\
\hline BPA & $(8.6 \pm 1.0) \times 10^{9} \mathrm{M}^{-1} \mathrm{~s}^{-1}$ & $(4.7 \pm 1.1) \times 10^{9} \mathrm{M}^{-1} \mathrm{~s}^{-1}$ & $(8.3 \pm 0.8) \times 10^{7} \mathrm{M}^{-1} \mathrm{~s}^{-1}$ & $(9.2 \pm 1.0) \times 10^{7} \mathrm{M}^{-1} \mathrm{~s}^{-1}$ \\
\hline STPW & $(2.9 \pm 0.4) \times 10^{3} \mathrm{~L} \mathrm{mgC}^{-1} \mathrm{~s}^{-1}$ & $(1.3 \pm 0.2) \times 10^{4} \mathrm{~L} \mathrm{mgC}^{-1} \mathrm{~s}^{-1}$ & & \\
\hline STPW* & $(6.1 \pm 1.1) \times 10^{3} \mathrm{~L} \mathrm{mgC}^{-1} \mathrm{~s}^{-1}$ & $(4.1 \pm 0.3) \times 10^{4} \mathrm{~L} \mathrm{mgC}^{-1} \mathrm{~s}^{-1}$ & & \\
\hline
\end{tabular}


Table 3. Percentage of photogenerated radicals reactivity in STPW and STPW*, on hydrogenocarbonates and on BPA estimated considering the pseudo-first order decay determined as products of the second order rate constant (obtained in this work or from literature) and initial concentrations.

\begin{tabular}{|c|c|c|c|c|c|}
\hline & & \multicolumn{2}{|c|}{$\mathrm{HO}^{\circ}$} & \multicolumn{2}{|c|}{$\mathrm{SO}_{4}{ }^{-}$} \\
\hline \multicolumn{2}{|c|}{ STPW } & \multicolumn{2}{|c|}{$98.4 \%$} & \multicolumn{2}{|c|}{$99.8 \%$} \\
\hline STPW* & $\mathrm{HCO}_{3}^{-}$ & $81.5 \%$ & $16.6 \%$ & $98.9 \%$ & $\sim 1 \%$ \\
\hline \multicolumn{2}{|c|}{ BPA } & \multicolumn{2}{|c|}{$1.6 \%$} & \multicolumn{2}{|c|}{$0.2 \%$} \\
\hline
\end{tabular}




\section{Figures Captions}

Figure 1: BPA degradation in the presence of $\mathrm{H}_{2} \mathrm{O}_{2}(2 \mathrm{mM})$ and $\mathrm{S}_{2} \mathrm{O}_{8}{ }^{2-}(2 \mathrm{mM})$ in buffered and unbuffered solutions at $\mathrm{pH} 8.0$ under UVA/B radiation.

Figure 2 Degradation profile of $\mathrm{BPA}\left([\mathrm{BPA}] /[\mathrm{BPA}]_{0}\right)$ at $\mathrm{pH} 4.6$ (full symbols) and 8.0 (empty symbols) using different chloride ions concentrations.

Figure 3 BPA degradation efficiency (DE) using different chloride ions concentrations at $\mathrm{pH} 8.0$ compared to the value obtained using $2 \mathrm{mM}$ of persulfate alone. Insert: effect of chloride ions using a linear scale for chloride ion concentration.

Figure 4: Modeled radical concentration in the system UVA/B- $\mathrm{S}_{2} \mathrm{O}_{8}{ }^{2-}(2 \mathrm{mM})$ in the presence of different chloride ions concentrations.

Figure 5: Inhibition effect of carbonates as a function of initial concentration and $\mathrm{pH}$ of solution toward the reactivity of hydroxyl (A) and sulfate $(\mathbf{B})$ radicals on BPA. An initial concentration of 43 $\mu \mathrm{M}$ of BPA is considered.

Figure 6: $\mathrm{BPA} 430 \mathrm{nM}\left(0.1 \mathrm{mg} \mathrm{\textrm {L } ^ { - 1 } )}\right.$ degradation in STPW using UVA/B- $\mathrm{H}_{2} \mathrm{O}_{2}(2 \mathrm{mM})$ and $\mathrm{UVA} / \mathrm{B}-\mathrm{S}_{2} \mathrm{O}_{8}{ }^{2-}(2 \mathrm{mM})$ system. STPW indicates sewage treatment plant water without any chemical modification; STPW* indicates sewage treatment plant water after removal of carbonates as indicated.

Figure 7: $4.3 \mu \mathrm{M}$ BPA degradation in STPW using $\mathrm{S}_{2} \mathrm{O}_{8}{ }^{2-}(2 \mathrm{mM})$ under UVA/B irradiation in the 
presence of $50 \mathrm{mM}$ of 2-propanol (2-Pr) and $50 \mathrm{mM}$ of tert-Butanol ( $t$-But). 


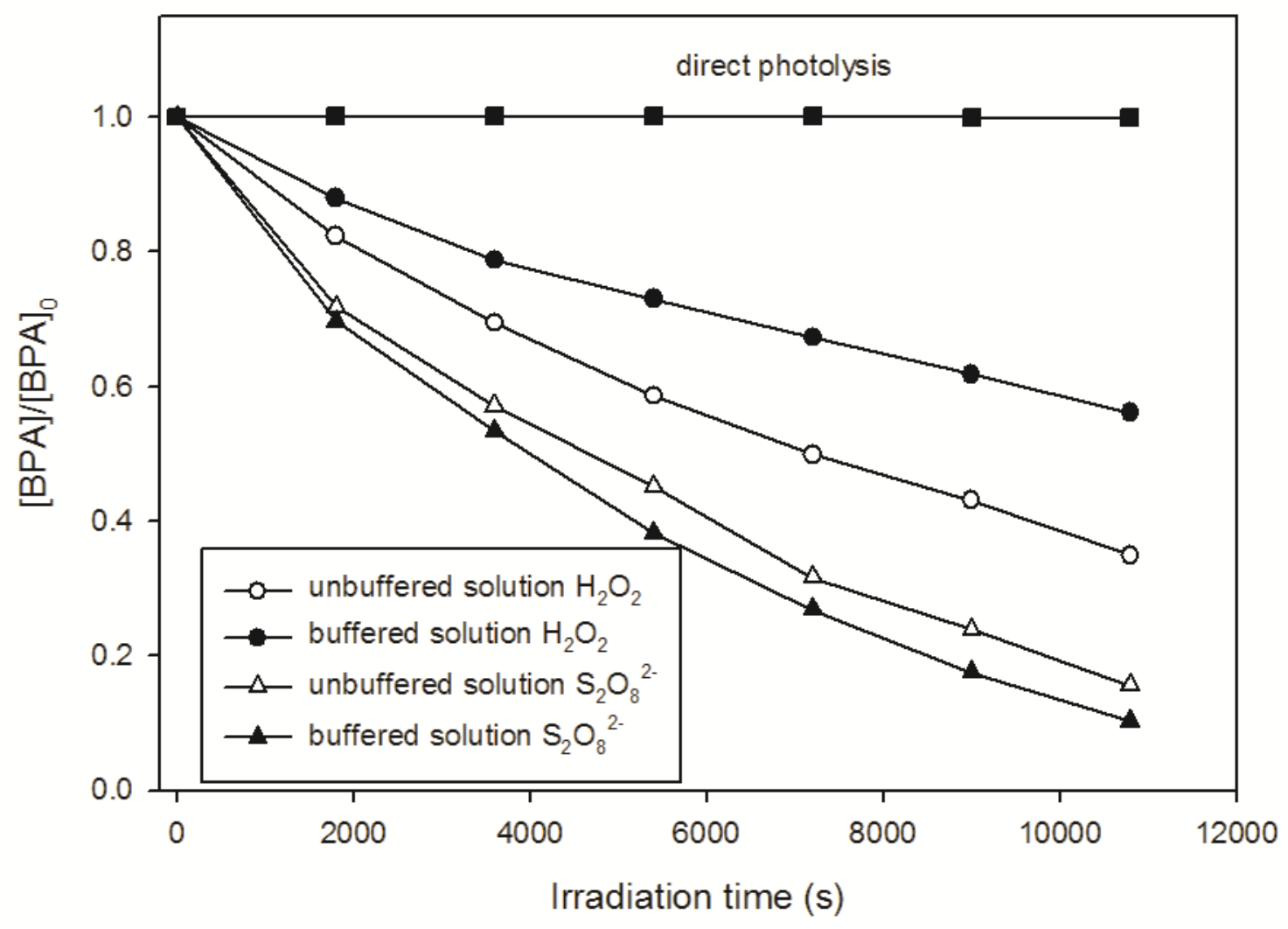

Figure 1 


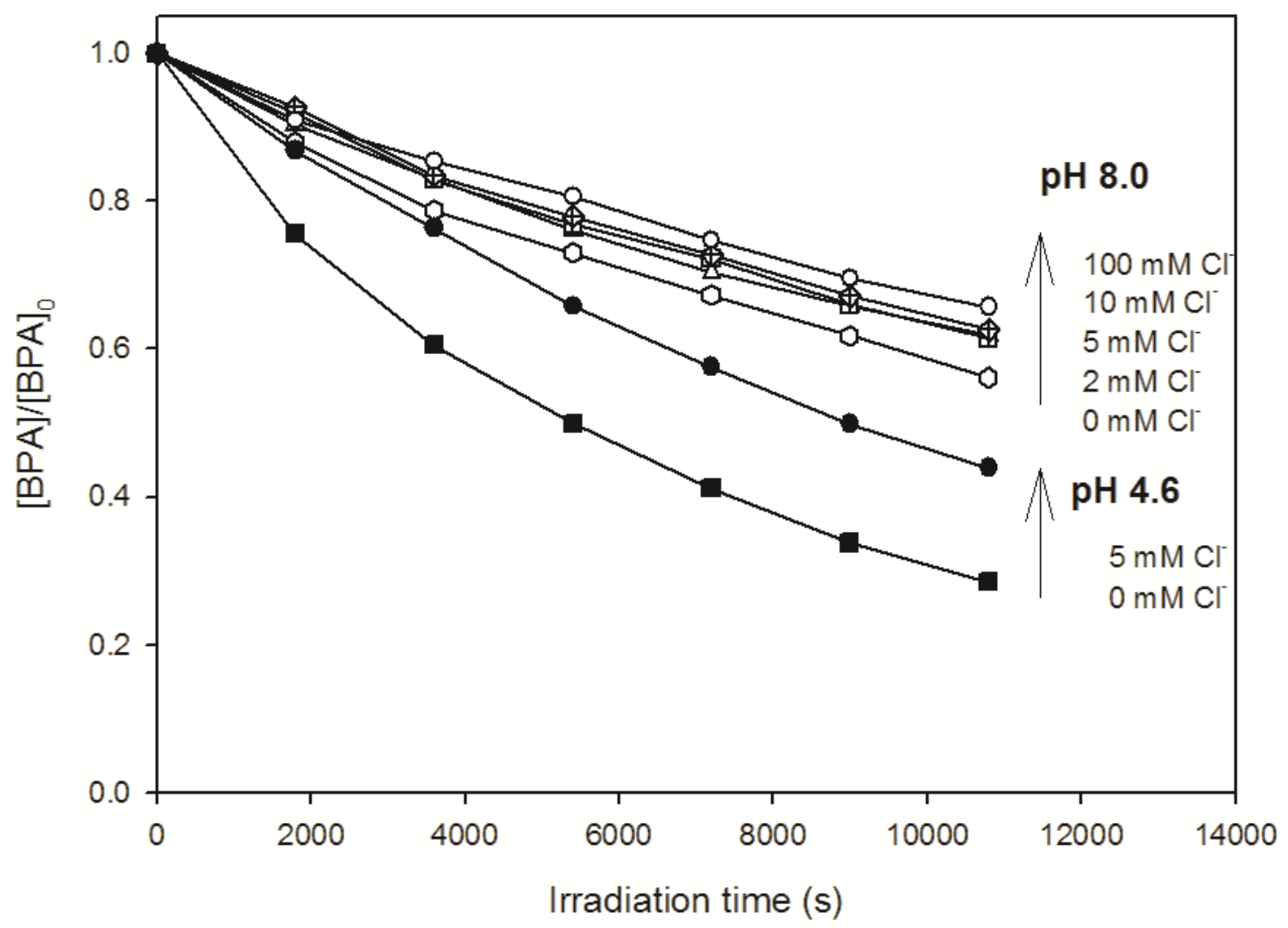

Figure 2 


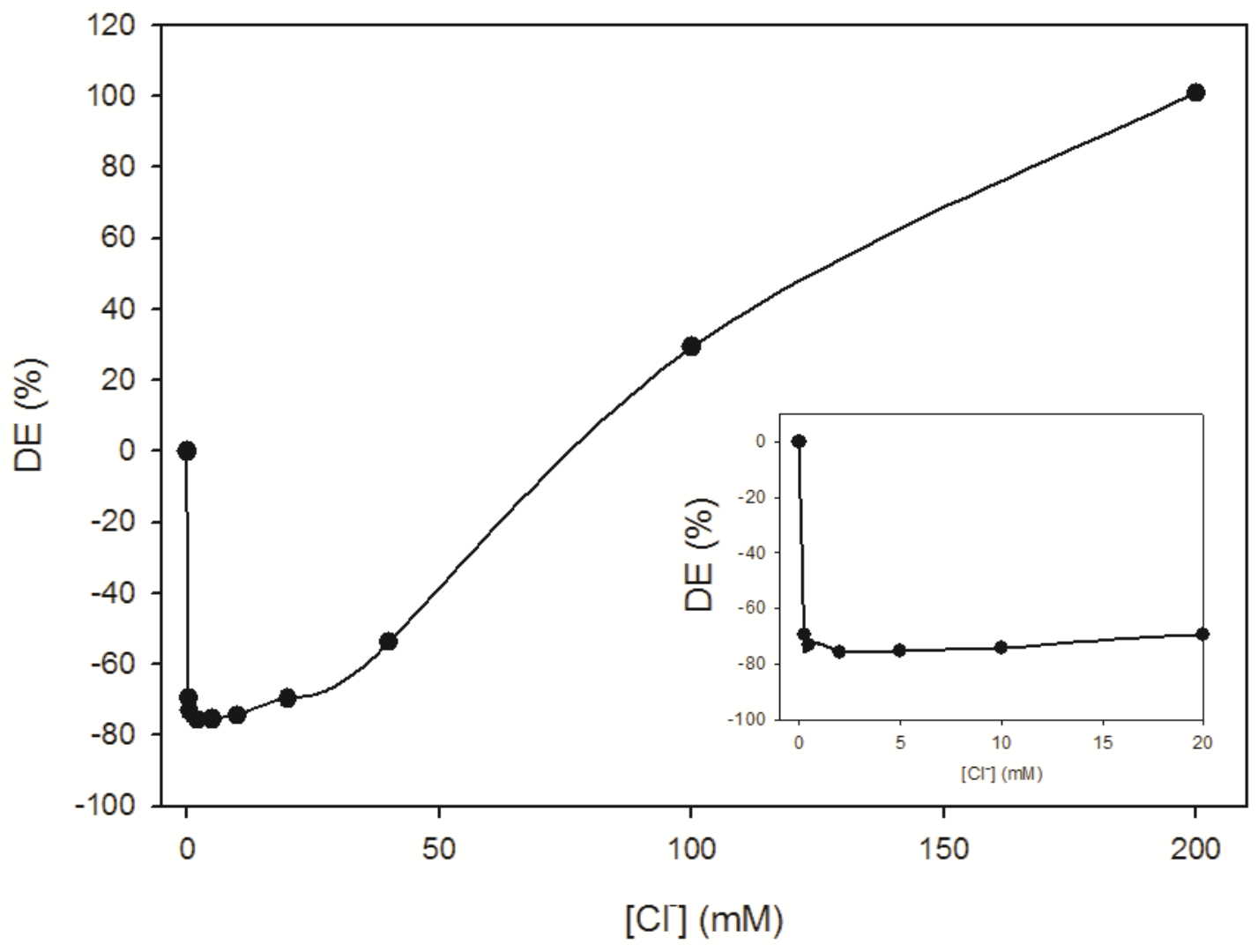

Figure 3 


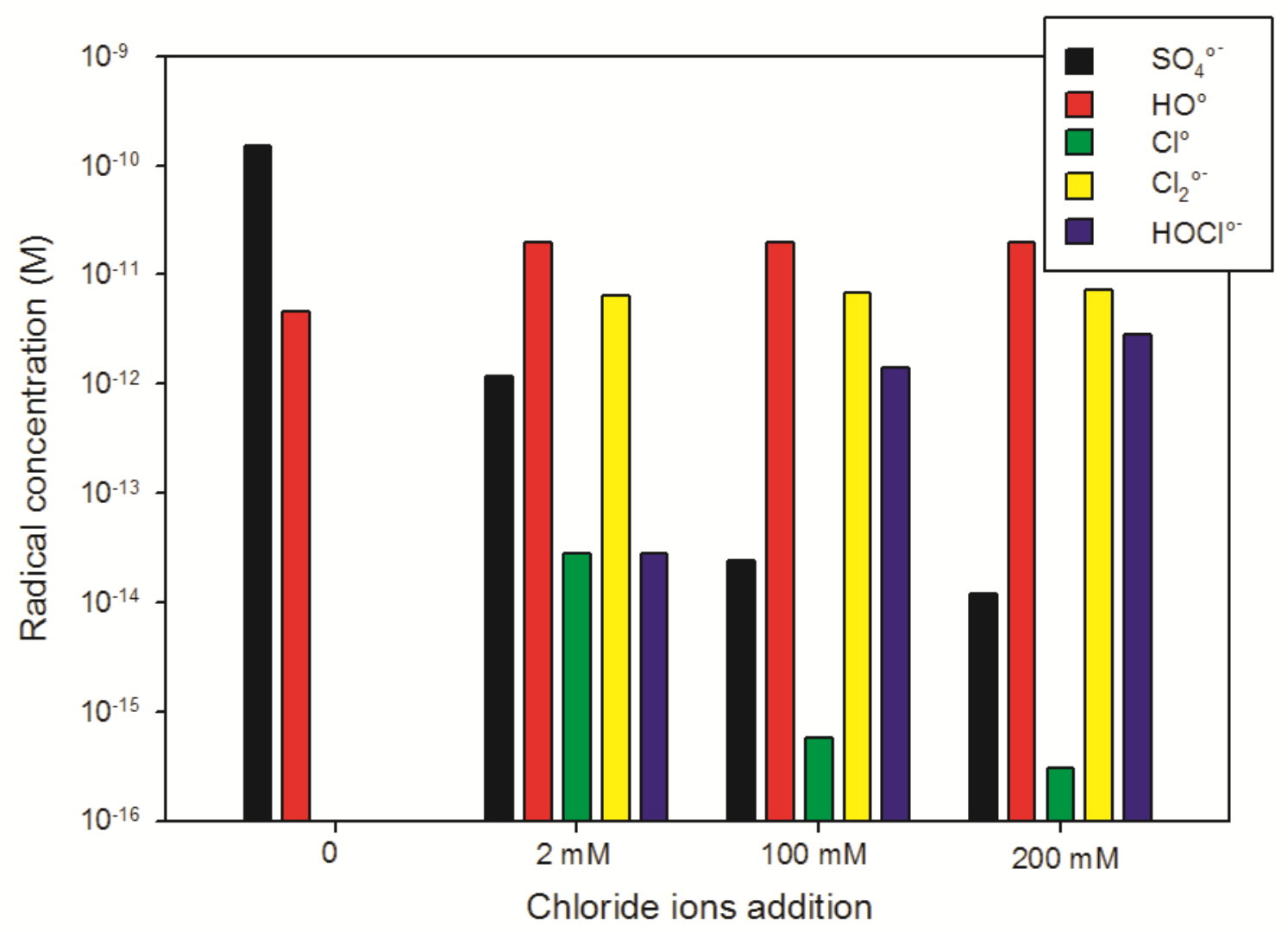

Figure 4 


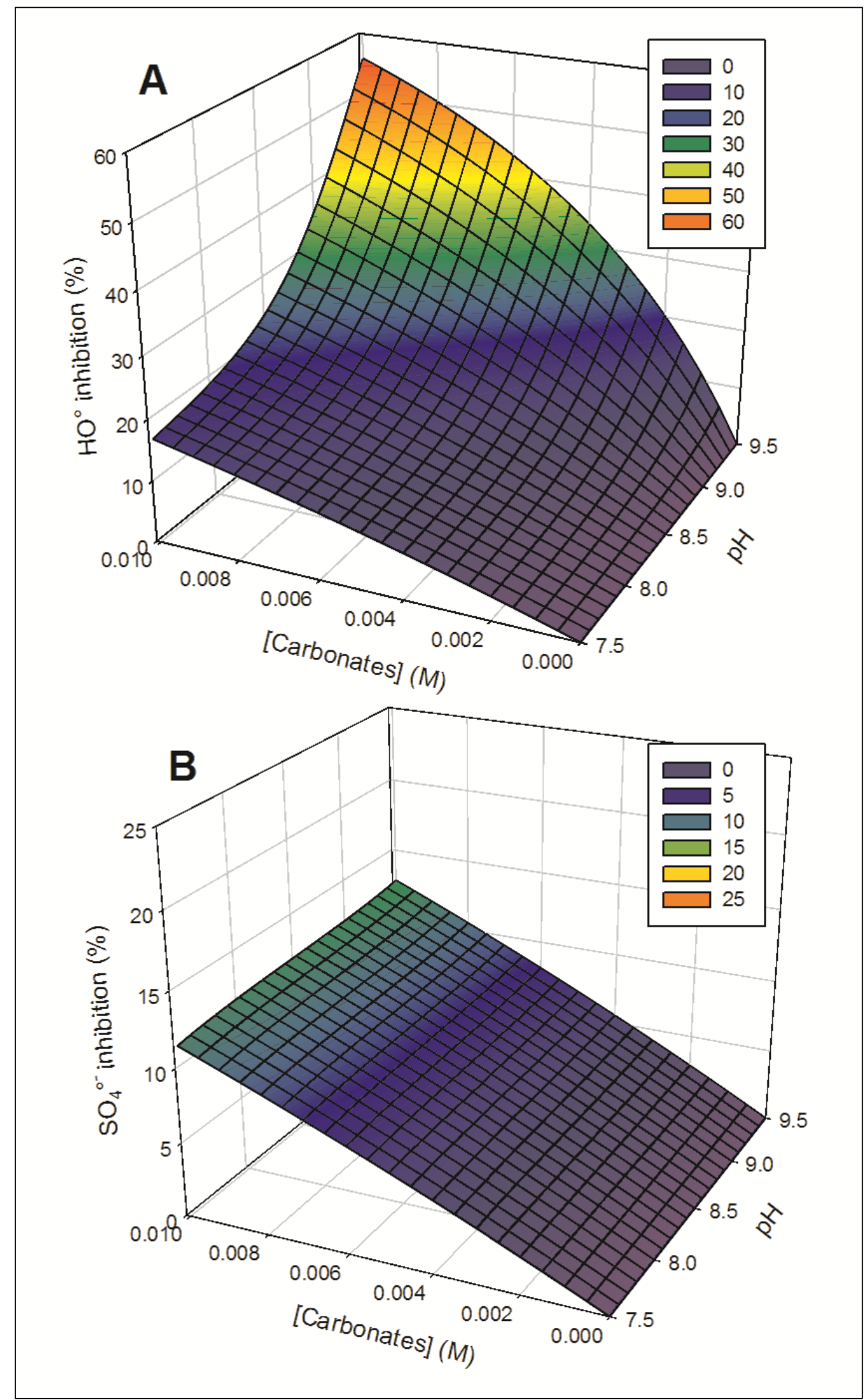

Figure 5 


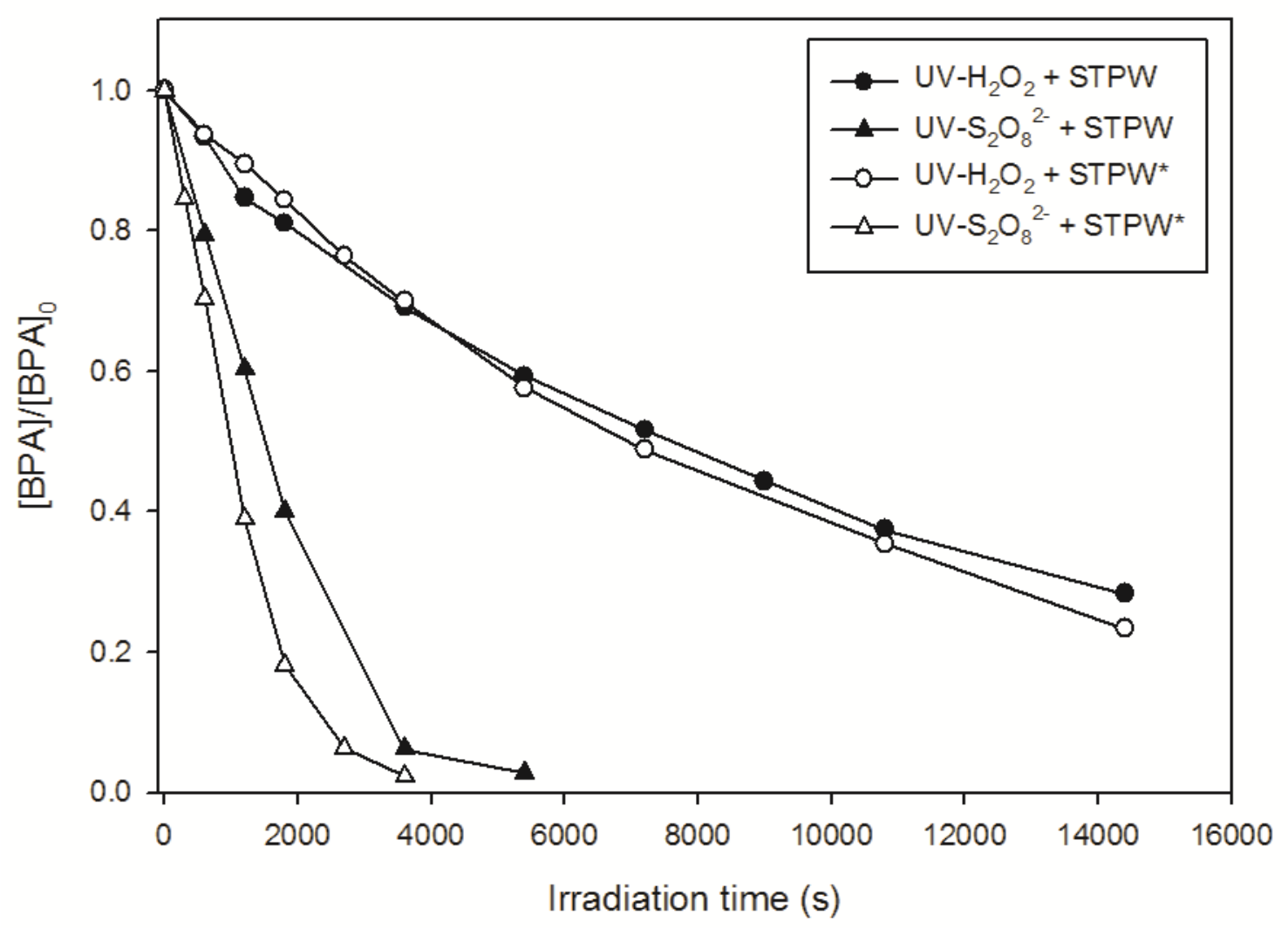

Figure 6 


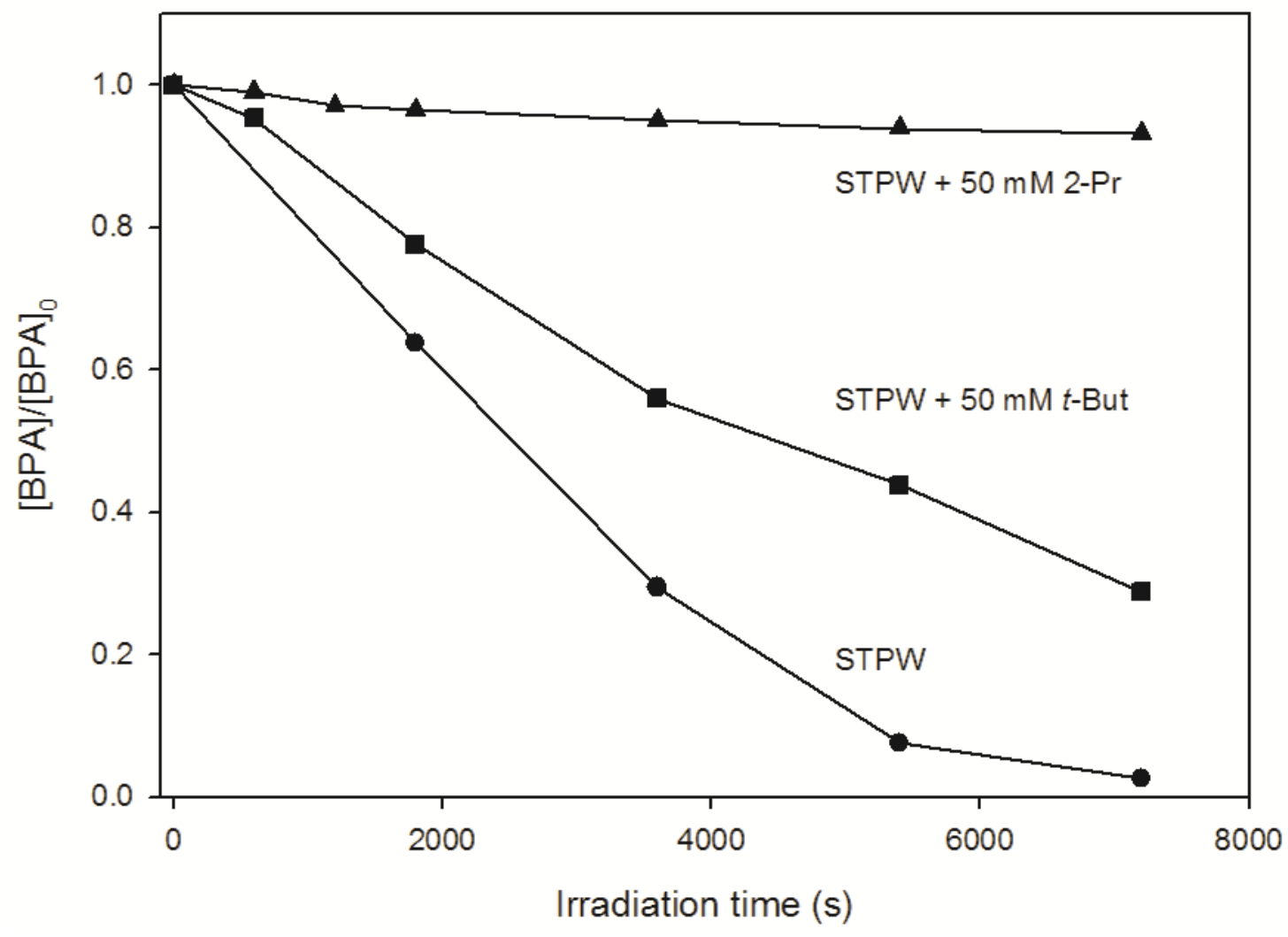

Figure 7 